\title{
SENTENCE MODIFIERS SEEMINGLY AND SURPRISINGLY AND THEIR TRANSLATION INTO CZECH
}

\section{Martina Jarkovská}

\section{Klíčová slova:}

větný modifikátor, obsahový disjunkt, větná (ne)začleněnost, větná realizace, adverbiální realizace, předložková fráze, intenzifikátor

\section{Keywords:}

sentence modifier, content disjunct, sentence (non)integration, clausal realisation, adverbial realisation, prepositional phrase, intensifier

\begin{abstract}
Abstrakt
Příspěvek se zabývá problematikou překladu adverbií odvozených příponou -ingly, které mají ve větě funkci obsahových větných modifikátorů hodnotících obsah sdělení z různých hledisek či postojů mluvčího. Činí tak na základě analýzy dvou nejfrekventovanějších disjunktů odvozených z přítomných participií surprisingly a seemingly. Obsahový (postojový) disjunkt surprisingly hodnotí obsah sdělení z hlediska neobvyklosti, zatímco epistemický postojový disjunkt seemingly vyjadřuje míru pochybnosti mluvčího. Ačkoliv tato příslovce ve své disjunktivní funkci převládají, jsou často homonymní s integrovanými syntaktickými funkcemi prríslovečných určení a intenzifikátorů, začleněných do větné stavby. Pro určení disjunktivní funkce je tedy důležitá jejich pozice ve větě a sémantická intepretace. Jelikož disjunkty odvozené $\mathrm{z}$ přítomných participií $\mathrm{v}$ češtině víceméně nemají odpovídající strukturální protějšky, jejich překlad se jeví jako problematický. Existující adverbiální ekvivalenty obvykle odpovídají příslovečným určením začleněným do větné stavby a nikoliv nezačleněným větným modifikátorům. Čeština tak pro překlad používá systém částic nebo větné realizace. Článek se zabývá vhodností různých typů překladu na základě porovnání anglických a českých protějšků dvou obsahových disjunktů surprisingly a seemingly.
\end{abstract}

\begin{abstract}
This article deals with the issues of translating -ingly adverbs functioning as content disjuncts. It does so on the example of the two most frequently used -ing participle based disjuncts surprisingly and seemingly. A judgement-value content disjunct surprisingly expresses the speaker's attitude to what is being said as unexpected whereas seemingly, a truth-value epistemic content disjunct expresses the speaker's degree of doubt. Although their disjunctive function prevails, they are homonymous with other, integrated manner or intensifying syntactic functions. Therefore, a careful analysis of their syntactic position in the sentence and their semantic interpretation are important to determine their non-integrated character and disjunctive function. Their translation into Czech seems to be problematic as -ingly disjuncts as their corresponding adverbial structural counterparts are more or less non-existent. Existing adverbial counterparts usually reflect the integrated nature of the adverbial and not its sentence modifying function. Czech thus makes use of particles and clausal realisations. This article focuses on the appropriateness of different types of translation comparing English and Czech versions of two content disjuncts: surprisingly and seemingly.
\end{abstract}




\section{Introduction}

Sentence modification is present in both languages, English and Czech; however, based on morphological and syntactic differences between the two languages, the means of Czech and English sentence modification do not always correspond. Above all, this is caused by the fact that -ingly adverbials, a productive class of disjuncts evaluating the content of the clause from the speaker's point of view, structurally more or less do not have Czech corresponding counterparts. In English -ing participle base adverbials can be regarded as condensed forms of clausal realization (surprisingly it is surprising). Although in Czech such adverbial forms are structurally possible, they are not in common usage (překvapujicí $\sim$ *prekvapujícně). This often results in applying different means of attitudinal evaluation as counterparts of -ingly disjuncts. Therefore a primary interest of this article is a comparison of stylistic differences in the sentence modification between English and Czech. The stylistic differences are illustrated on the two content disjuncts, surprisingly and seemingly.

As for its semantic interpretation, a value-judgment content disjunct surprisingly expresses a judgment of what is said to be strange or unexpected. As Huddleston et al. $(2002,771)$ say, the residual proposition is presented as a fact and the disjunct expresses the speaker's evaluation of it. In this respect content disjuncts are subjective since they evaluate the content of the proposition in terms of the attitude of the speaker. Content disjuncts can be paraphrased by the adjectival construction it is adjective that... or ..., which is adjective. The truth-value disjunct seemingly, expressing a degree of doubt, allows only the verbal paraphrase it seems that...

Disjuncts cannot serve as an answer to the question "How? " (Dušková 1994, 474). The fact that in spoken language disjuncts function as separate intonation units is in writing often reflected in punctuation. The article is concerned with findings from written language only; therefore the feature of intonation is excluded from the analysis.

\section{Material and method of analysis}

Since this is a contrastive study, the existence of the Czech translation of the English original was therefore a primary condition for the selection of the material for the analysis. However, this condition turned out to be a problem when selecting literary sources and their authorized translations from different registers. In general, fiction turned out to be the most available literary source translated. The situation was much more complicated with non-fiction, where the choice of translated literature is conceivably smaller. Usually, most academic literature is not translated and texts are often available only in the original. The language of other registers, e.g. newspapers and magazines, administrative writing, which is not translated at all or seldom, was therefore disregarded in the analysis from the beginning.

Consequently, the scope of the research was stylistically limited. It concerned fictional and non-fictional prose, with non-fictional prose represented by academic prose and literature of fact.

As regards texts of contemporary British and American fiction, sixteen English originals and their respective Czech translations were used as sources for data collection. The dates of their publication fall within the period of the late twentieth and the beginning of the twenty-first century. They are written in the form of social, humourist, and detective novels.

As for non-fiction, eight texts of academic prose and four texts of literature of fact were researched. The texts of British and American academic prose are from the sphere of social science, i.e. they deal with the subject matter of psychology, theology, politology, art and 
linguistics. Eight English originals and their respective Czech translations were researched. Literature of fact is represented by two Czech originals and their respective English translations and two English originals and their Czech translations, written in the form of political and philosophical essays, commentaries and letters.

All the texts described above were available in paper version and were researched manually.

The majority of texts used as sources in the analysis are a part of the English-Czech section of the research project Czech National Corpus and Corpora of Other Languages, the English Section, VZ 002160823; http://ucnk.ff.cuni.cz, henceforth CNCCOL. Twenty-five scanned texts and their translations were researched. As regards the language of the originals, there were researched eighteen scanned English originals and their respective Czech translations and seven scanned Czech originals and their respective English translations. The original sources represent American, British and Czech fiction of the twentieth century and, correspondingly to the manually researched fiction, they are written in the form of social and humourist novels, fantasy and romance.

The starting point for the analysis was the occurrence of adverbs surprisingly and seemingly in the English version of the text, be it the original or the translation of the original. The approach to the analysis was therefore two-directional.

\section{Syntactic function}

The adverbial suffix $-l y$ is, in general, considered a feature of manner adverbials (Huddleston et al. 2002, 670, Dušková 1994, 455). According to Huddleston et al. (2002, 565) most deadjectival adverbials ending in the suffix $-l y$ primarily allow the paraphrase in an adjective manner or to an adjective degree. Those deadjectival adverbials that do allow such interpretations usually have other meanings as well. In Table 1 below the syntactic functions of -ingly adverbs surprisingly and seemingly are presented.

Table 1: Syntactic functions of adverbs seemingly and surprisingly

\begin{tabular}{|l|l|l|l|l|}
\hline & $\begin{array}{l}\text { non-integrated } \\
\text { disjunct }\end{array}$ & $\begin{array}{l}\text { integrated } \\
\text { intensifier }\end{array}$ & $\begin{array}{l}\text { pre-modifier within a clause } \\
\text { element following a } \\
\text { preposition or an overt } \\
\text { determiner }\end{array}$ & total \\
\hline seemingly & 32 & 22 & 23 & 77 \\
\hline surprisingly & 44 & 39 & 26 & 109 \\
\hline
\end{tabular}

The obtained data reveal that -ingly adverbs seemingly and surprisingly which are among most frequent value-judgement and truth-value disjuncts prevail in their sentence modifying function over other integrated functions. Surprisingly functioned as a disjunct in 44 instances being followed by 39 instances in which it functioned as an intensifier. Seemingly functioned in 32 instances as a sentence modifier and altogether in 22 instances as an intensifier. It must not be forgotten that many such occurrences are subject to syntactic homonymy:

If one female saint out of eleven seems surprisingly little, the reason may well be that the others were eclipsed by the Virgin Mary, in her many forms, such as the Mother of Mercy (with supplicants sheltering under her cloak), the Virgin of the Rosary or the 
Virgin of Loreto (the Italian town to which the "holy house" from Bethlehem was said to have been miraculously transported). ${ }^{1}$

= If one female saint out of eleven is little, which seems surprising... (disjunct)

$=$ If one female saint out of eleven seems really little,... (intensifier)

The level of syntactic integration is in the first place conditioned by the position of the adverbial in a sentence. However, syntactic positions contain both non-integrated and integrated adverbials and there are instances in which the level of integration remains undecided.

As Bolinger $(1965,288)$ states, the initial placement of the adverbial reflects its meaning "as a rule" and the adverbial colours or modifies everything that follows, i.e. the whole sentence. Thus the initial position is regarded as a signal of wide scope adverbials, extending over the whole sentence and modifying it. It is a position typical for content disjuncts. Therefore, almost any adverbial derived from the attitudinal participial adjective could be regarded as a disjunct in this position.

The use of punctuation in the initial position cannot be taken as the sole feature signalling the disjunctive function of the adverbial. The semantic attitudinal interpretation is important as well in order to rule out the manner adjunct meaning of the adverbial and its integration into the clause. On the other hand, if the attitudinal adjectival paraphrase is applicable and the adverbial satisfies the syntactic criteria test applied so that its syntactic integration can be excluded, in the initial position the disjunctive function of the adverbial, even if not detached by punctuation, is indisputable:

Not surprisingly there's a slightly weary cynicism in people's reaction when you speak approvingly of the Velvet Revolution. ${ }^{2}$

Seemingly it's turned out better than we feared. ${ }^{3}$

As regards the medial position, this position is quoted by grammar books as the position common for disjuncts expressing epistemic modality (Quirk et al. 1985, 628). Also Biber et al. (1999, 872) say that disjuncts (stance adverbials), in their analysed corpora, display a preference for medial position. This proved true for a truth-value disjunct seemingly in the corpus which preferred the medial position while a value-judgement disjunct surprisingly, as all content disjuncts, favoured the initial position. According to Quirk et al. $(1985,94)$ it is perfectly normal for content disjuncts to appear in medial position between the operator and the verb - in a post-auxiliary position. The data show that post-auxiliary position is common especially for truth-value disjuncts, which frequently occur in this position without separation by punctuation.

At first the self-coding may be just an accompaniment of the forbidden activity, which is seemingly not hindered by it, but careful observation shows that the child is experiencing something of a conflict and the sudden appearance of an adult may throw it into confusion. ${ }^{4}$

\footnotetext{
${ }^{1}$ Burke, P. The Italian Rennaissance: Culture and Society in Italy, Polity Press, Cambridge, 1986, p. 168

${ }^{2}$ Lodge, D. Thinks..., Penguin Books, England, 2002, p. 216

${ }^{3}$ Peters, E. Brother Cadfael's Penance, Warner Future, London, 1995, p. 167

${ }^{4}$ Adcock, C.J. Fundamentals of Psychology, Penguin Books, England, 1964, p. 118
} 
Value-judgment disjuncts, on the contrary, prefer pre-verbal position, i.e. the position after the subject before the operator or the first auxiliary. However, in both positions, pre-verbal or post-auxiliary, value-judgment disjuncts tend to be separated from the rest of the sentence by means of punctuation to avoid homonymy with narrow scope adverbials.

Some of the sharing is, not surprisingly, between kin, but much takes place within partnerships - two or more unrelated bats that recognize each other by distinctive "contact calls" and often groom each other.

Among the findings there was only one occurrence of -ingly adverb surprisingly in the disjunctive function of value-judgment on the clause content that was not detached from the rest of the sentence by means of punctuation, although in the medial position. If the context makes it clear that the adverbial functions as a disjunct, it is not necessary to separate the adverbial by punctuation (Greenbaum 1969, 185).

And don't tell me, Dr. Witherspoon went on, that I am looping on the dark side. Do not tell me that there aren't still craftsmen today who make good and reliable things, or that it isn't still, for instance, possible to get furniture at which the heart rejoices, such as wardrobes that [[surprisingly]] enough open, without having to be shaken first, and bookcases whose glass fronts slide across without difficulty. Don't tell me that there's no more of the type of furniture that will keep its quality for decades. ${ }^{6}$

However, to avoid homonymy with intensifiers or manner adjuncts in the medial position, the separation of content disjuncts by punctuation is favoured. Its significance is indispensable in the end position. Punctuation is in this case crucial to mark their peripheral character and their non-integration into the sentence. If not separated, they fall under the scope of verbal predication and become integrated adjuncts functioning as either optional or obligatory verb complements:

At least he and his half-brother have always respected and liked each other, seemingly, although all the Clares are absolute for Stephen, and this chance brother chose the empress. $^{7}$

"Including our relationship, [[surprisingly]] enough." ${ }^{8}$

Last but not least, many adverbs in question (23 occurrences of seemingly and 26 occurrences of surprisingly) have occurred as integrated into a noun phrase following either an overt determiner or a preposition:

A surprisingly small bundle was returned by Bilquis to the midwife, who bore it out to the anxious father. ${ }^{9}$

Between mouthfuls of surprisingly tasty chip butty, Caroline explained where they were heading. ${ }^{10}$

\footnotetext{
${ }^{5}$ Wright, R. The Moral Animal, Evolutionary Psychology and Everyday Life, Little, Brown and Company, UK, 1994, p. 203

${ }^{6}$ The Czech National Corpus and Corpora of Other Languages, the English Section, VZ 002160823 (CNCCOL), Jirotka, Z., Saturnin, verifiable at http://ucnk.ff.cuni.cz.

${ }^{7}$ Peters, E. Brother Cadfael's Penance, Warner Futura, London, 1995, p.111

${ }^{8}$ CNCCOL, Vievegh, M., Bringing up Girls in Bohemia

${ }^{9}$ Rushdie, S. Shame, Pan Books, London, 1983, p. 89
} 
Although they are not part of this adverbial analysis, they cannot be left out if an overall picture of all -ingly adverbial occurrences of both adverbs seemingly and surprisingly in the corpus is to be given.

\section{Relevance of English $\rightarrow$ Czech and Czech $\rightarrow$ English translation}

The translation of content disjuncts which convey some evaluation of what is being said seems to be the most problematic. This regards especially the open class of -ingly content disjuncts. Considering their formal realization, they are derived from the present participles by the suffix $-l y$, which is one of the features of the word class of adverbs (surprising $\rightarrow$ surprisingly). In Czech such constructions are structurally possible (překvapujicí $\rightarrow$ prekvapujicně, podivujicí $\rightarrow$ podivujícně); however, in standard usage they are not acceptable. Czech thus has to make use of other types of realizations to express the meaning of these sentence adverbials. In many cases translators select a sentence particle (e.g. bohužel, naštěstí, kupodivu) or they apply a corresponding clausal modification (Je překvapující, že... ..., což je prekvapujicí) (Pátík 1993).

What is more, when translating -ingly disjuncts into Czech, the translator cannot rely on the help of dictionaries, which only seldom reflect the polysemantic nature of English adverbials and often list the meaning of adverbs in their adjunctive function only (Malinovský 1990).

According to Malinovský (cf. 1990) the tendency not to differentiate the disjunctive function from the adjunct function is not limited to Czech dictionaries only; such practice is also common for British lexicography. Therefore, several most frequently used dictionaries of the English language have been consulted and their entries of the disjunct surprisingly compared with the occurrences from our corpus. For instance, in The Oxford English Dictionary (1972) only the interpretation in a surprising manner or degree is listed (1972: Volume II, 3176). In Longman Dictionary of Contemporary English (1995, 1454) surprisingly, besides having the degree interpretation (The exam was surprisingly easy), is defined as a sentence adverbial (Not surprisingly, the UK has the highest divorce rate in the community). In Longman Dictionary of the English Language $(1984,44)$ the adverb surprisingly, included in the dictionary entry of the adjective surprising, is defined as an adverb of a nature that causes surprise (1984, 1511). In Hais, Hodek (1984), the adverb surprisingly, is not listed as a dictionary entry at all. In Fronek (2006) for surprisingly equivalents neočekávaně, překvapivě and also kupodivu, napodiv and proti všemu očekávání are given (2006, 1496).

According to Pátík (1993) it depends on the individual translator's taste and feeling for language, what type of translation s/he chooses. The translation of the English sentential modification is a matter of choice from several possibilities - adverbial, clausal or noun realization.

Table 2 below presents an overall quantification of different types of translation of disjuncts seemingly and surprisingly found in the corpus.

\footnotetext{
${ }^{10}$ McDermid, V. Killing the Shadows, St. Martin's Minotaur, New York, 2000, p. 369
} 
Table 2: The types of translation of -ingly adverbs functioning as disjuncts

\begin{tabular}{|l|c|c|c|c|c|c|c|}
\hline $\begin{array}{l}\text { formal } \\
\text { realization } \\
\text { of translation }\end{array}$ & \multicolumn{2}{|c|}{ clause } & \multicolumn{2}{c|}{ adverbial } & \multicolumn{2}{c|}{$\begin{array}{c}\text { prep. } \\
\text { phrase }\end{array}$} & $\begin{array}{l}\text { total } \\
\mathbf{1 0 0 \%}\end{array}$ \\
\hline disjunct & abs. & $\%$ & abs. & $\%$ & abs. & $\%$ & \\
\hline seemingly & 8 & 27.6 & 21 & 72.4 & & & 29 \\
\hline surprisingly & 23 & 52.3 & 19 & 43.2 & 2 & 4.5 & 44 \\
\hline
\end{tabular}

The data in Table 2 reveal that in the translation of the value-judgment disjunct surprisingly clausal realization $(52.3 \%)$ prevailed over adverbial realization $(43.2 \%)$. When translating the truth-value disjunct seemingly, the trend was opposite. The translation by adverbials $(72.4 \%)$ considerably prevailed over the translation by a clause $(27.6 \%)$. The translation by a clause very literally captures the semantic meaning and scope of attitudinal disjunct adverbials in English. The clausal realizations more or less copy the attitudinal paraphrase of the adverbial. In fictional prose, where the demand for explicitness and "straightforwardness" of the translation is not so strict, slight modifications of this type of translation can be observed. However, the basic pattern of the clausal realization, i.e. the attitudinal evaluation expressed explicitly by a verbal predicate in the main clause has been retained:

Not surprisingly, most of the residents refuse. ${ }^{11}$

Není divu, že většina obyvatel odmítne. ${ }^{12}$

Seemingly, he had spent months of work to explain a trivial illusion. ${ }^{13}$

Mohlo by se zdát, že obětoval měsíce práce jen na to, aby vysvětlil triviální klam. ${ }^{14}$

At a children's picnic parents may be induced to race, with many of them putting up a very poor performance and yet seemingly little worried by their lack of success. ${ }^{15}$

Na dětském pikniku se mohou rodiče dát svést $\mathrm{k}$ tomu, aby závodili, přičemž mnozí z nich podávají velice chabý výkon - a přece se nezdá, že by svým neúspěchem nějak trpěli. ${ }^{16}$

Washington proceeded to "cut the cancer out" by violence and, not surprisingly considering the array of forces, with great success. ${ }^{17}$

Nakonec se mu, byt` za použití násilí, podařilo nádor „,vyříznout“. Vítězství USA ani nemohlo být velkým překvapením, uvážíme-li, v jaké byly převaze. ${ }^{18}$

The attitudinal evaluation may also be expressed by a pseudo-adverbial or pseudo-relative clause either embedded into the sentence or attached to the end. In semi-direct or direct speech in fictional prose the translation often has a form of an embedded clause of a parenthetic nature.

\footnotetext{
${ }^{11}$ Hunt, M. The Story of Psychology, Doubleday, New York, 1993, p. 399

${ }^{12}$ Hunt, M. Dějiny psychologie, translation Renáta Mlíkovská and Ivo Müller, Portál, Praha, 2000, p. 379

${ }^{13}$ Hunt, M. The Story of Psychology, Doubleday, New York, 1993, p. 283

${ }^{14}$ Hunt, M. Dějiny psychologie, translation Renáta Mlíkovská and Ivo Müller, Portál, Praha, 2000, p. 269

${ }_{15}$ Adcock, C.J. Fundamentals of Psychology, Penguin Books, England, 1964, p. 126

${ }_{16}^{16}$ Adcock, C.J. Základy psychologie, translation Marie Hejlová, Orbis, Praha, 1973, p. 123

${ }^{17}$ Chomsky, N. Hegemony of Survival. America's Quest for Global Dominance, Penguin Books, London, 2004, p. 98

${ }^{18}$ Chomsky, N. Hegemonie nebo přežití. Americké tažení za globální nadvládou, translation Adéla Vopěnková,

Mladá fronta, Praha, 2006, p. 128
} 
He sounded a little tetchy yesterday evening, not surprisingly. ${ }^{19}$

Zdál se mi včera trochu podrážděný, a není divu. ${ }^{20}$

In example above, however, the translation sounds rather colloquial in comparison to stylistically neutral surprisingly. The translation corresponds rather to a sentence adverbial no wonder, which can also be regarded as colloquial.

It is the translation by lexical items - sentence adverbials - that seems to be problematic and calls for further discussion.

Table 3: Czech adverbial counterparts of surprisingly and seemingly

\begin{tabular}{|c|c|c|c|c|c|c|c|c|c|}
\hline $\begin{array}{l}\text { English } \\
\text { disjunct }\end{array}$ & $\%$ & $\begin{array}{l}\text { Czech } \\
\text { adverbial }\end{array}$ & abs. & $\%$ & $\begin{array}{l}\text { English } \\
\text { disjunct }\end{array}$ & $\%$ & $\begin{array}{l}\text { Czech } \\
\text { adverbial }\end{array}$ & abs. & $\%$ \\
\hline \multirow{7}{*}{ seemingly } & \multirow{7}{*}{21} & žrejmě & 7 & 33.3 & \multirow{7}{*}{$\begin{array}{l}\text { surprisingly } \\
\text { (enough) }\end{array}$} & \multirow{7}{*}{19} & kupodivu & 11 & 57.9 \\
\hline & & zdánlivě & 5 & 23.8 & & & překvapivě & 5 & 26.3 \\
\hline & & očividně & 5 & 23.8 & & & pochopitelně & 2 & 10.5 \\
\hline & & jakoby & 1 & 4.8 & & & \multirow[t]{4}{*}{ samozřejmě } & \multirow[t]{4}{*}{1} & \multirow[t]{4}{*}{5.3} \\
\hline & & zjevně & 1 & 4.8 & & & & & \\
\hline & & prý & 1 & 4.8 & & & & & \\
\hline & & naoko & 1 & 4.8 & & & & & \\
\hline
\end{tabular}

The examples quoted below, in which the attitudinal evaluation conveyed by the original disjunct has been altered to such an extent that it no longer corresponds to the context and consequently the meaning has been changed, are marked by an asterisk as not fitting. As the data reveal, the choice of a particular sentence adverbial may cause a shift in meaning between the Czech sentence particle and the attitudinal evaluation conveyed by the English adverbial. Sometimes the adverbial translation involves a change on the scale of stylistic markedness as well. The former may be illustrated by očividně, which occurred as an equivalent of seemingly.

He asked his students questions that seemingly led them step by step to discover the truth for themselves. ${ }^{21}$

Kladl studentům otázky, které je *očividně krok za krokem vedly k tomu, aby sami pro sebe objevili pravdu. ${ }^{22}$

The English disjunct does not commit itself to the truth-value of the content but only expresses what it appears to be, which is reflected by the corresponding adverbial zdánlivě whereas očividne belongs to the opposite side on the scale of epistemic modality; it reinforces the degree of truth of the content. The other shift, a change on the scale of stylistic markedness, is particularly obvious in the case of the adverbial prekvapiver, which, besides kupodivu also occurred as an equivalent of the disjunct surprisingly. Unlike the stylistically neutral English adverbial, překvapivě is felt by most speakers as stylistically marked, bookish.

\footnotetext{
${ }^{19}$ Lodge, D. Thinks..., Penguin Books, England, 2002, 298

${ }^{20}$ Lodge, D. (2001), Profesorské hrátky, translation Eva Kondrysová, Academia, Praha, 2001, p. 312

${ }^{21}$ Hunt, M. The Story of Psychology, Doubleday, New York, 1993, p. 20

${ }^{22}$ Hunt, M. Dějiny psychologie, translation Renáta Mlíkovská and Ivo Müller, Portál, Praha, 2000, p. 31
} 
Surprisingly, when people are asked whether the voice is theirs, they are, on average, right less often than is their GSR. ${ }^{23}$

Když mají lidé poznat, zda poslouchají nahrávku svého hlasu, překvapivě se spletou častěji než jejich GSR. ${ }^{24}$

From Table 3 it further appears that there are also examples of a shift in understanding a disjunct as a connective adverbial. Žrejmě, whose dictionary equivalent is evidently, comes in such contexts near to tedy, which has a connective function. The speaker's attitude regards the whole argument, and it is a connecting link in a sequence of logical conclusions. According to Poldauf (1964), zřejmě and other expressions of this type, like patrně (evidently), sice (that is) or vlastné (in fact) are then close to connectives.

Seemingly it's turned out better than we feared. ${ }^{25}$

*Zřejmě to dopadlo líp, než jsme se obávali. ${ }^{26}$

The attitudinal evaluation often overlaps with epistemic modality. The use of the modal particle samožrejmě, which expresses a very high degree of the speaker's conviction about the truth-value of the content of the communication, is not totally inappropriate; it is only a stronger expression which evaluates the content of the sentence as something expected - as a neutral consequence.

Not [[surprisingly]], Claire took offense and slammed down the knife she'd been paring the potatoes with. ${ }^{27}$

Claire se samožrejmě hned namíchla a praštila s nožem, kterým krájela brambory. ${ }^{28}$

However, there are even greater discrepancies in meaning when other adverbial equivalents of -ingly disjuncts are taken into account. As previous examples have shown (cf. Table 3), the English adverbial surprisingly has been translated into Czech most frequently by the adverbials kupodivu and prekvapivé, which are more or less semantically appropriate equivalents. However, in the findings these two Czech adverbials also occurred as equivalents of other English disjuncts, in some instance not semantically corresponding to one another.

There is yet another example where the translation from the Czech original into English is not accurate. The particle pry conveys the evaluation based on the judgment of others, excluding the speaker, and as such it does not express the truth-value of the content. This is in contrast to seemingly, whose weakened truth-value modality includes not only the speaker/author but also other persons involved.

Celý text je *prý záměrně narušován vlnami bezobsažnosti (odkazujícími podle Beáty na staletý boj Holand'anů s mořem) a v rytmu jeho vět je rovněž možné vystopovat rytmus původních nástrojů mexických Indiánů, aztécké flétny a chrastítka sonajas. ${ }^{29}$

The entire text was [[seemingly]] deliberately interspersed with waves of emptiness (a reference, according to Beata, to the Dutch people's centuries of struggle with the

\footnotetext{
${ }^{23}$ Wright, R. The Moral Animal, Evolutionary Psychology and Everyday Life, Little, Brown and Company, UK, 1994, p. 270

${ }^{24}$ Wright, R. Morální zvíře, proč jsme to, co jsme, translation Antonín Hradílek, Nakladatelství Lidové noviny, Praha, 2002, p. 262

${ }^{25}$ Peters, E. Brother Cadfael's Penance, Warner Futura, London, 1995, p.167

${ }^{26}$ Petersová, E. Pokání bratra Cadfaela, translation Stanislava Pošustová, Mladá fronta, Praha, 2004, p. 140

${ }^{27}$ CNCCOL, Lindsey, J., Loving Scoundrel

${ }^{28}$ CNCCOL, Lindsey, J., Zamilovaný ničema

${ }^{29}$ CNCCOL, Vievegh, M., Výchova dívek v Čechách
} 
sea), and one could also detect in the rhythm of his text the rhythm of original musical instruments of the Mexican Indians: the Aztec flute and the sonajas rattle. ${ }^{30}$

\section{Conclusion}

The changes in meaning and different types of evaluation that can be encountered when comparing the translation of -ingly disjuncts into Czech when translated by sentence adverbials are first and foremost caused by the fact that many of the -ingly adverbials which can function as disjuncts lack adverbial counterparts that could be used in a sentence modifying function. If the translator does not make use of a clausal realization, s/he has to select a sentence particle whose meaning often does not correspond to the meaning conveyed by the English adverbial. This practice has been partially seen in the adverbial equivalents of surprisingly and seemingly. From the observations it can be concluded that when translating ingly adverbials in their disjunctive function into Czech, special attention must be paid to the choice of the adverbial which would best correspond to the semantic meaning of the English disjunct in question. Even though it is possible to find adverbial equivalents of some such adverbs in Czech, these only seldom reflect the disjunctive function of the adverbial in English and the integrated manner or intensifying interpretation prevails.

\section{Literature:}

[1] BIBER, D., JOHANSSON, S., FINEGAN, E., LEECH, G., CONRAD, S. Longman Grammar of Spoken and Written English. $1^{\text {st }}$ ed. Harlow: Longman, 1999, ISBN: 0-58223725-4.

[2] BOLINGER, D. L. Linear Modification. In Forms of English. $1^{\text {st }}$ ed. Cambridge, MA: Harvard University Press, 1965, p. 279-307, ISBN: 90-040-4572-4.

[3] DUŠKOVÁ, L., et al. Mluvnice současné angličtiny na pozadí češtiny. 2. vyd. Praha: Academia, 1994, ISBN: 80-200-0486-6.

[4] FRONEK, J. Velký anglicko-český slovník, Leda, Praha, 2006, ISBN: 80-7335-022-X.

[5] GREENBAUM, S. Studies in English Adverbial Usage. $1^{\text {st }}$ ed. London: Longman, 1969, ISBN: 0-87-024137-0.

[6] HAIS, K., HODEK, B. Velký anglicko-český slovník, Academia, Praha, 1984, ISBN: 978-80-7335-022-2.

[7] HUDDLESTON, R., PULlUM, G. K. The Cambridge Grammar of the English Language, Cambridge University Press, 2002, ISBN: 0521431468.

[8] Longman Dictionary of Contemporary English, Longman, London, 1995, ISBN: 9781408215333.

[9] Longman Dictionary of the English Language, Longman, London, 1984, ISBN: 0-58255511-6.

[10] MALINOVSKÝ, M. O tzv. disjunktech. Slovo a slovesnost, 51, 48 - 54, 1990, ISSN: 0037-7031.

[11] MALINOVSKÝ, M. Zpracování větných příslovcí (disjunktů) v novodobých slovnících angličtiny, Philologica Pragensia 33, 17-20, 1990, ISSN: 1211-2054.

[12] The Oxford English Dictionary, Oxford University Press, 1972, ISBN: 9780300089196.

[13] PÁTÍK, R. On some stylistic and translation aspects of English sentence modifiers, Prague Studies in English 20, 149-164, 1993, ISSN: 1801-8858.

\footnotetext{
${ }^{30}$ CNCCOL, Vievegh, M., Bringing up Girls in Bohemia
} 
[14] POLDAUF, I. The Third Syntactical Plan, Travaux linguistiques de Prague 1, 241 - 255, 1964.

[15] QUIRK, R., GREENBAUM, S., LEECH, G., SVARTVIK, J. A Comprehensive Grammar of the English Language. $1^{\text {st }}$ ed. London: Longman, 1985, ISBN: 0-58296502-0.

\section{Corpus:}

[1] Adams, D. The Hitchhiker's Guide around the Galaxy. In The ultimate hitchhiker's guide - Complete \& unabridged. New York: Wings Books, 1996, ISBN: 0-517-14925-7.

[2] Adams, D. Stopařùv průvodce po galaxii. Translation Jana Hollanová, Praha: Odeon, 1991, ISBN: 80-207-0229-6.

[3] Adams, D. Restaurant at the End of the Universe. In The ultimate hitchhiker's guide Complete \& unabridged. New York: Wings Books, 1996, ISBN: 0-517-14925-7.

[4] Adams, D. Restaurant na konci vesmíru. Translation Jana Hollanová, Praha: Odeon, 1991, ISBN: 80-207-0229-6.

[5] Adcock, C.J. Fundamentals of Psychology. London: Penguin Books, 1964, ISBN: 9780140206647.

[6] Adcock, C.J. Základy psychologie. Translation Marie Hejlová, Praha: Orbis, 1973, ISBN: 80-221-0186-9.

[7] Burke, P. Popular Culture in Early Modern Times. Ashgate, 2002, ISBN: 1859281028.

[8] Burke, P. Lidová kultura v raně novověké Evropě. Translation Markéta Kř́žzová, Praha: Argo, 2005, ISBN: 80-7203-638-6.

[9] Burke, P. The Italian Rennaissance: Culture and Society in Italy. Cambridge: Polity Press, 1986, ISBN: 0-7456-2137-6.

[10] Burke, P. Italská renesance: Kultura a společnost v Itálii. Translation Jiří Kropáček, Mladá fronta, Praha, 1996, ISBN: 80-204-0589-5.

[11] Caldwell, I., Thomason, D. The Rule of Four. New York: The Dial Press, 2004, ISBN: 0-385-33711-6.

[12] Caldwell, I., Thomason, D. Pravidlo čtyř - Záhada Belladonna. Translation Petr Pomezný, Praha: Baronet, 2005, ISBN: 80-7214-770-6.

[13] Chomsky, N. Syntactic Structures. The Hague: Mouton \& Co., 1971, ISBN: 0-72048604-1.

[14] Chomsky, N. Syntaktické struktury. Translation Zdeněk Hlavsa, Praha: Academia, 1966, ISBN: 80-7178-445-1.

[15] Chomsky, N. Hegemony of Survival. America's Quest for Global Dominance. London: Penguin Books, 2004, ISBN: 978-0-141-01505-7.

[16] Chomsky, N. Hegemonie nebo přežití. Americké tažení za globální nadvládou. Translation Adéla Vopěnková, Praha: Mladá fronta, 2006, ISBN: 80-204-1351-0.

[17] Farrell, J.G. Troubles. Harmondsworth: Penguin Books Ltd., 1981, ISBN: 0-224-61900-4.

[18] Farrell, J.G. Nepokoje. Translation Martin Hilský, Praha: Odeon, 1989, ISBN: 80-2070001-3.

[19] Farrell, J. G. The Siege of Krishnapur, London: Weidenfeld and Nicolson, 1973, ISBN: 0297765809.

[20] Farrell, J. G. Obléhání Krišnapuru. Translation Jan Starý, Praha: Odeon, 1990, ISBN: 80-207-0160-5.

[21] Fulghum, R. All I Really Need to Know I Learned in Kindergarten. New York: Villard Books, 1988, ISBN: 0-394-57102-9.

[22] Fulghum, R. Všechno, co opravdu potřebuju znát, jsem se naučil v mateřské školce. Translation Jiří Hrubý, Praha: Odeon, 1993, ISBN: 80-207-0434-5. 
[23] Fulghum, R. It Was on Fire When I Lay Down on It, New York: Villard Books, 1989, ISBN: 0-394-58056-7.

[24] Fulghum, R. Už hořela, když jsem si do ní lehal. Translation Jiří Hrubý, Praha: Odeon, 1993, ISBN: 80-207-0439-6.

[25] Havel, V. Dálkový výslech. New York: Vintage Books, 1990, ISBN: 80-7023-042-8.

[26] Havel, V. Disturbing the Peace, A Conversation with Karel Hvížd`ala. Translation Paul Wilson, New York: Vintage Books, 1990, ISBN: 0-679-73402-3.

[27] Havel, V. Letters to Olga. Translation Paul Wilson, London: Faber and Faber, 1990, ISBN: 0-571-14213-3.

[28] Havel, V. Dopisy Olze (červen 1979 - záŕí 1982). Brno: Atlantis, 1990, ISBN: 80-7108009-8.

[29] Heywood, A. Political Ideologies. Basingstoke: Macmillan, 1992, ISBN: 0-333-54936-8.

[30] Heywood, A. Politické ideologie. Translation Zdeněk Masopust, Praha: Eurolex Bohemia, 2005, ISBN: 80-86861-71-6.

[31] Hunt, M. The Story of Psychology. New York: Doubleday, 1993, ISBN: 0-385-24762-1.

[32] Hunt, M. Dějiny psychologie. Translation Renáta Mlíkovská and Ivo Müller, Praha: Portál, 2000, ISBN: 80-7367-175-1.

[33] James, P. D. Devices and Desires. London: Faber and Faber Limited, 1989, ISBN: 0571-14304-0.

[34] Jamesová, P. D. Plány a touhy. Translation Luba and Rudolf Pellar, Praha: Odeon, 1993, ISBN: 80-207-0465-5.

[35] Lodge, D. Nice Work. London: Secker \& Warburg, 1988, ISBN: 0-436-25667-3.

[36] Lodge, D. Pěkná práce. Translation Miloš Calda, Praha: Nakladatelství Svoboda Libertas, 1989, ISBN: 80-205-0294-7.

[37] Lodge, D. Thinks... Harmondsworth: Penguin Books Ltd., 2001, ISBN: 0-14-200086-8.

[38] Lodge, D. Profesorské hrátky. Translation Eva Kondrysová, Praha: Academia, 2002, ISBN: 80-200-1038-6.

[39] McDermid, V. Killing the Shadows. New York: St. Martin's Minotaur, 2000, ISBN: 0312-26615-4.

[40] McDermidová, V. Vraždění stínů. Translation Jarmila Kroupová, Praha: BB art, 2003, ISBN: 80-7257-936-3.

[41] McDermid, V. The Torment of Others. New York: St. Martin's Minotaur, 2004, ISBN: 0-312-33919-4.

[42] McDermidová, V. Utrpení jiných. Translation Radmila Damová, Praha: BB/art, 2005, ISBN: 80-7341-454-6.

[43] Merton, T. The Waters of Siloe. New York: Garden City Books, 1951, ISBN: 0-85969090-3.

[44] Merton, T. Vody Siloe. Translation Daniel Nečas, Praha: Krystal OP, 2007, ISBN: $978-$ 80-85929-90-4.

[45] Moore, T. Soul Mates: Honoring the Mysteries of love and relationship. New York: Harper Colins Publishers, 1994, ISBN: 0-06-016928-1.

[46] Moore, T. Kniha o lásce a přátelství: pohled hlubinné psychologie a spirituálních tradic na mezilidské vztahy. Translation Jiří Foltýn, Praha: Portál, 1998, ISBN: 80-7178-160-6.

[47] Peters, E. Brother Cadfael's Penance. London: Warner Futura, 1995, ISBN: 07515 13709.

[48] Petersová, E. Pokání bratra Cadfaela. Translation Stanislava Pošustová, Praha: Mladá fronta, 2004, ISBN: 80-204-1175-5.

[49] Rushdie, S. Shame. London: Pan Books, 1983, ISBN: 0-39-453408-5.

[50] Rushdie, S. Hanba. Translation Pavel Dominik, Praha: Odeon, 1990, ISBN: 80-2070173-7. 
[51] Rushdie, S. The Moor's Last Sigh. London: Vintage, The Random House, 1995, ISBN: 0-09-959241-X.

[52] Rushdie, S. Maurův poslední vzdech. Translation Pavel Dominik, Praha: Mladá fronta, 1999, ISBN: 80-204-0768-5.

[53] Sanders, L. The Eighth Commandment. New York: G. P. Putnam's Sons, 1986, ISBN: 0-399-13125-6.

[54] Sanders, L. Osmé přikázání. Translation Vladimír Eisenbruk and Pavla Slabá, Praha: Svoboda - Libertas, 1992, ISBN: 80-205-0280-7.

[55] Wright, R. The Moral Animal, Evolutionary Psychology and Everyday Life. London: Little, Brown and Company, 1994, ISBN: 0316875015.

[56] Wright, R. Morální zvî́re, proč jsme to, co jsme. Translation Antonín Hradílek, Praha: Nakladatelství Lidové noviny, 2002, ISBN: 80-7106-612-5.

The Czech National Corpus and Corpora of Other Languages (CNCCOL), the English Section, VZ 002160823, Praha: Institute of the Czech National Corpus, verifiable at http://ucnk.ff.cuni.cz

\section{JEL Y900}

\section{PhDr. Martina Jarkovská, Ph.D.}

Department of Languages

Faculty of Economics and Management

Czech University of Life Sciences Prague

Kamýcká 129

16521 Prague 6 - Suchdol

jarkovska@pef.czu.cz 